\title{
Argali Ovis ammon surveys in Mongolia's South Gobi
}

\author{
Richard P. Reading, Sukhiin Amgalanbaatar, Henry Mix and Badamjaviin \\ Lhagvasuren
}

The argali, Ovis ammon, a species of wild sheep, is threatened in Mongolia, suffering from poaching and competition with domestic livestock. The authors conducted ground and aerial surveys of argali in Dundgobi, Omnogobi and Dornogobi aimags (or provinces) of the South Gobi region of Mongolia. Ground surveys were conducted by vehicle and on foot, while aerial surveys were conducted using two Soviet $A \dot{N}-2$ aircraft flying $40-\mathrm{km}$ parallel transects. The interactive computer programme Distance was used to estimate population size and density. The authors observed a total of 423 argali in 85 groups (mean group size $=5.0 \pm 0.6 \mathrm{SE}$ ), including 300 individuals in 61 groups on the ground survey (mean size $=4.9 \pm 0.8 \mathrm{SE}$ ) and 123 animals in 24 groups during the aerial survey (mean size $=5.1 \pm 1.2$ SE). Population structure of the groups observed during the ground survey was 14.3 per cent males, 53.3 per cent females, 19.7 per cent lambs, and 12.7 per cent animals of undetermined sex (means $=0.7 \pm 0.2 \mathrm{SE}$ males, $2.6 \pm 0.6$ SE females, $1.0 \pm 0.2$ SE lambs, and $0.6 \pm 0.4$ SE undetermined). We estimated a population size of $3900 \pm 1132$ SE argali in the study area for a population density of $0.0187 \pm 0.0054$ SE animals $/ \mathrm{sq} \mathrm{km}$. More rigorous and comprehensive surveys for argali, preferably for each distinct population, should be conducted for more accurate estimates. Argali require more active conservation and management, especially with respect to poaching and competition with domestic livestock. If sport hunting is to continue, a large portion of all money

\section{Introduction}

The argali Ovis ammon is a large mountain sheep inhabiting the mountains, steppecovered valleys, and rocky outcrops of Mongolia and neighbouring countries. Two subspecies, the Altai argali O.a.ammon and Gobi argali O.a. darwini (although the taxonomy of the Gobi subspecies is unclear, and it has been classified as mongolica, hodgsoni, kozlovi, and more; see Tsalkin, 1951; Zhirnov and Ilyinsky, 1986; Geist, 1991) live in the mountainous regions of northern and western Mongolia and the mountains, valleys and rocky outcrops of the Gobi desert and Gobisteppe areas of Mongolia, respectively (Dulamtseren, 1970; Sukhbat, 1978; Mallon, 1985a, b; Shagdarsuren et al., 1987; Geist, 1991; Luschekina, 1994; Mallon et al., 1997).

The argali is listed as threatened in the Mongolian Red Book of threatened and endangered species (Shagdarsuren et al., 1987) and included in Appendix II of the Convention on International Trade of Endangered Species of Flora and Fauna (CITES). Both subspecies are listed in the 1996 IUCN Red List of Threatened Animals, with the Altai argali classified as Vulnerable and the Gobi argali as Endangered (IUCN, 1996). Although protected from general hunting since 1953 (foreign sport hunting is still permitted), poaching continues to be an important source of mortality (Zhirnov and Ilyinsky, 1986; Shagdarsuren et al., 1987; Luschekina, 1994; 
Mallon et al., 1997). The USA classified the Mongolian argali as Threatened on its Endangered Species List (Nowak, 1993) because its status was not clear and because US authorities require, among other things, that hunted species be actively managed and that money generated from hunting fees be used to manage the species. Because of its large size and impressive horns, the argali is highly prized by foreign sport hunters, who paid over \$US20 million to kill 1630 males from 1967 to 1989 (Amgalanbaatar, 1993a; Luschekina, 1994). Currently 70 per cent of the money generated from argali hunting goes to the general treasury of the nation, 10 per cent to the sum (county) government in which the animal was harvested and 20 per cent to the hunting organization (Luschekina, 1994; Wingard, 1996; Mallon et al., 1997). Little or none of this money is used for argali conservation.

The argali also suffers from competition for water and forage with domestic livestock, especially in the Altai Mountain regions (Gruzdev and Sukhbat, 1982; Zhirnov and Ilyinsky, 1986; Shagdarsuren et al., 1987; Amgalanbaatar and McCarthy, 1993; Luschekina, 1994; Mallon et al., 1997). Recent ground surveys for both argali subspecies suggest that numbers of Altai argali may be low and declining, but that a relatively healthy population of Gobi argali exists (Amgalanbaatar and McCarthy, 1993; Valdez and Frisina, 1993; Luschekina, 1994; Schaller 1994). However, previous research on and monitoring of argali has been sporadic and not comprehensive (see review by Luschekina, 1994 and Mallon et al., 1997). This study was undertaken to estimate the population size of Gobi argali in the South Gobi region of Mongolia using ground and aerial surveys.

\section{Study Area}

The study area included portions of Dundgobi, Omnogobi and Dornogobi aimags (provinces) and varies from true desert through semidesert to Gobi-steppe (Zhirnov and Ilyinsky, 1986; Tsegmid and Vorobev, 1990; Figure 1). The flora and fauna are repre- sentative of the arid regions of Central Asia. The region is characterized as a high upland (around $1000 \mathrm{~m}$ ) with dry stream beds and hummocks, rocky outcrops and mountain massifs rising to over $800 \mathrm{~m}$ above the surrounding landscape. Springs and other water sources are rare. The climate is strongly continental and arid, characterized by cold winters (to $-35^{\circ} \mathrm{C}$ ), dry, windy springs (to $5 \mathrm{mps}$ ), and relatively wet, hot summers (to $40^{\circ} \mathrm{C}$ ). Precipitation is low, averaging $127.2 \mathrm{~mm} / \mathrm{yr}$ in Omnogobi and $116.7 \mathrm{~mm} / \mathrm{yr}$ in Dornogobi.

Vegetation is sparse, especially in the southern regions, and generally increases northward. Plants of the Gobi steppe include Stipa klemenzii, Stipa gobica, Salsola passerina, Thymus gobica, Cleistogenes squarrosa, Ajania fructiculosia, Artemisia frigida and Artemisia rutifolia. The semi-desert regions are characterized by semi-shrubs, shrubs, and some grasses; plants include Ajania fructiculosa, Stipa gobica, Stipa glareosa, Caragana korshinskii, Caragana pygmaea, Scorzonera capito, Lagochilus ilicifolius, Artemisia frigida and Haloxylon ammodendron. The true Gobi desert contains little vegetation. Semi-shrubs, shrubs and scrub vegetation dominate, and plants include Zygophyllum xanthoxylon, Salsola passerina, Anabasis brevifolia, Caragana leucophloea and Haloxylon ammodendron. For more detail see Zhironv and Ilyinsky (1986) and Tsegmid and Vorobev (1990).

\section{Methods}

A limited ground survey for argali and other large mammals was conducted in August 1994 in six sums (Tsogtsetsii, Nomgon, Manlai, Khanbogd, Khankhongor and Bayan-Ovoo) of Omnogobi aimag and 10 sums (Mandakh, Khatanbulag, Ulaanbadrakh, Khovsgol, Erdene, Urgon, Saikhandulaan, Airag, Dalanjargalan and Sumber) of Dornogobi aimag. Argali were observed from a vehicle or on foot, but in all cases positive identification was made using binoculars and a spotting scope. We recorded sex and age (lamb or adult) of all animals observed when possible. Mountains or rocky outcrops in which argali 


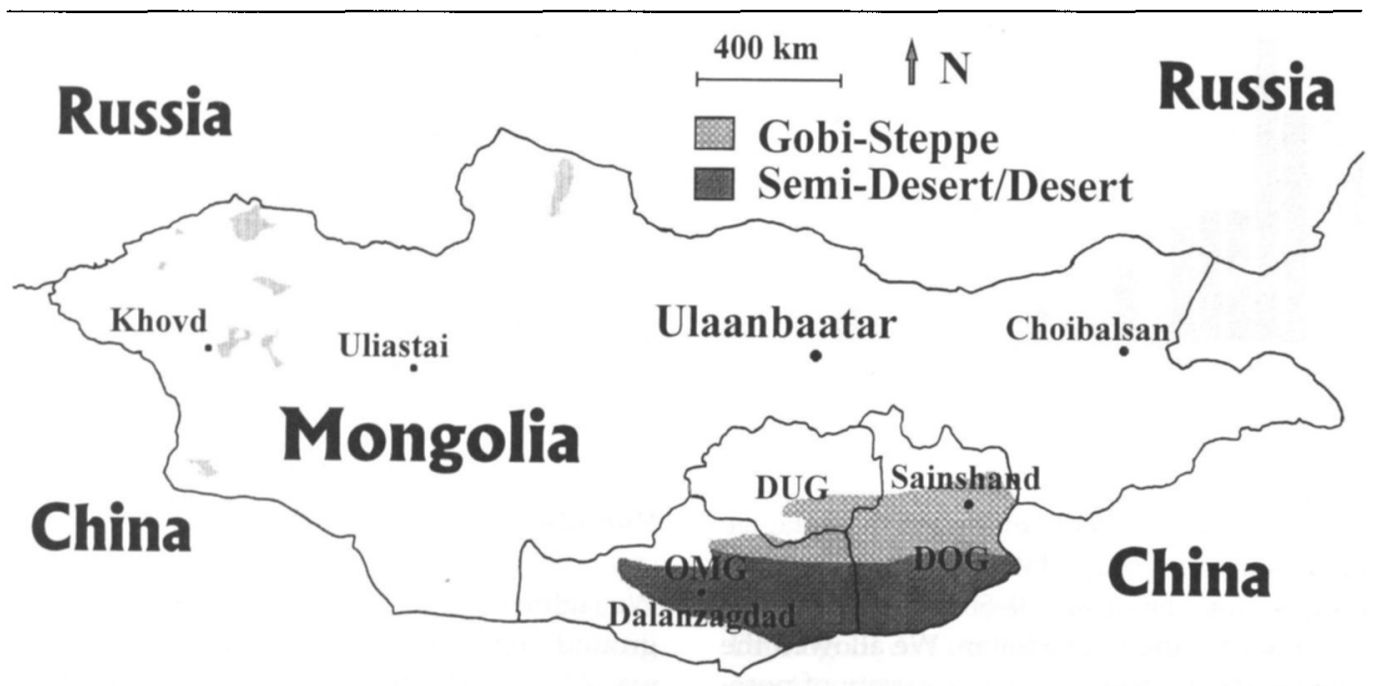

Figure 1. Aerial survey area in Mongolia's South Gobi. DUG, Dundgobi aimag; DOG, Dornogobi aimag; OMG, Omnogobi aimag.

were sighted from the vehicle or known to occur in the past were investigated by foot. The survey covered $1476 \mathrm{~km}$ by vehicle and approximately $100 \mathrm{~km}$ by foot.

A pre-rut aerial survey of South Gobi was conducted from 22 to 25 and on 27 October 1994 (5 days of flying). The survey included the south-eastern third of Dundgobi aimag, the central and eastern parts of Omnogobi aimag, and the southern three-quarters of Dornogobi aimag (Figure 1). Data were collected on all large mammals sighted and were stratified by ecological zone and aimag.

We followed the guidelines proposed by Burnham et al. (1980) for conducting line transect surveys where possible. Surveys were conducted flying two Soviet AN-2 biplanes approximately $100 \mathrm{~m}$ over the ground surface. Average cruising speed was $170 \mathrm{~km} / \mathrm{h}$. Although faster than desirable, flight speed was constrained by the aircraft available in Mongolia. This problem was partially compensated for by the number of people and amount of equipment the aircraft could carry. We placed two observers on each side of each aircraft, as well as one in the front. All observers had experience performing large mammal surveys. Each aircraft also included one person taking still photographs, and we equipped one plane with a video camera. Film from both sources was used to photo-verify the data from observers. We flew straight, parallel routes separated by approximately $40 \mathrm{~km}$ (although distance varied somewhat for logistic reasons, such as refuelling) using a global positioning system for navigation. When a group of argali was sighted, we recorded estimated group size, group composition if possible, estimated perpendicular distance from the transect line (to the nearest $100 \mathrm{~m}$ ), and time. We flew from approximately 10.00 to $12.45 \mathrm{~h}$ and 14.00 to $16.30 \mathrm{~h}$ on the first day using two aircraft, from 9.20 to $12.00 \mathrm{~h}$ on the second day using one aircraft, from 9.45 to $12.00 \mathrm{~h}$ and 14.00 to $17.00 \mathrm{~h}$ on the third day using two aircraft, from 10.00 to $14.00 \mathrm{~h}$ on the fourth day using two aircraft in the morning (one until $11.30 \mathrm{~h}$ ), and from 9.00 to $11.45 \mathrm{~h}$ on the fifth day using two aircraft.

Variables were tested for homogeneity of group variance using Bartlett's test and were examined for normality. Where necessary, variables were normalized using natural logarithms. Pairwise comparisons of sample means were made using $t$-tests. We estimated argali density, group density and population size using the interactive computer program DISTANCE (Laake et al., 1993). To obtain an 


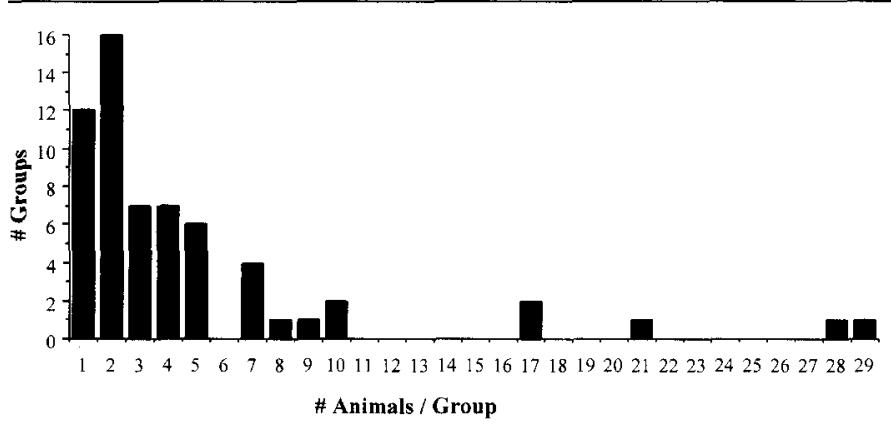

Figure 2. Frequency of argali group sizes $(N=61$, mean $=4.9 \pm$ $0.8 \mathrm{SE}$ ) observed during ground surveys in the South Gobi, Mongolia. Note the highly skewed (2.74) and kurtotic (7.79) distribution.

estimate that accurately modelled the data, we pooled argali group data into four distance classes for analysis: $0-500 \mathrm{~m}, 500-750 \mathrm{~m}$, $750-1500 \mathrm{~m}$, and over $1500 \mathrm{~m}$. We allowed the programme to select among a variety of possible estimators, including half normal, negative exponential, hazard-rate, and uniform models based on minimum Akaike information criterion $\left(-2^{*} \ln\right.$-likelihood $+2 \mathrm{~m}$, where $\mathrm{m}=$ the number of parameters; see Laake et al., 1993). A uniform estimator $-k(y)=1 / W$, where $k=$ the number of samples, $y=$ distance, and $W=$ the width of the line transect with cosine adjustments of order 1 was selected whose probability detection function model was not significantly different from the distribution of actual observations $\left(\chi^{2}=1.70, P\right.$ $=0.43$, d.f. $=2)$, using a Chi-square goodness of fit test (Burnham et al., 1980, 1985; Buckland et al., 1993, Laake et al., 1993).

\section{Results}

We sighted 300 argali in 61 groups during the ground survey (Table 1). Average group size was $4.9 \pm 0.8 \mathrm{SE}$ (range 1-29; Figure 2). Overall we recorded 43 (14.3 per cent) males, 160 (53.3 per cent) females, 59 (19.7 per cent) lambs, and 38 (12.7 per cent) animals of undetermined sex. Male to female ratio was therefore 26.9:100, and lamb to female ratio was 36.9:100. Group structure averaged $0.7 \pm 0.2$ $\mathrm{SE}$ males, $2.6 \pm 0.5 \mathrm{SE}$ females, $1.0 \pm 0.2 \mathrm{SE}$ lambs, and $0.6 \pm 0.4 \mathrm{SE}$ undetermined animals.

We separated observations by aimag for analysis. In Omnogobi aimag we observed 154 argali in 35 groups, with a mean group size of $4.4 \pm 0.9 \mathrm{SE}$. The population structure of the Omnogobi argali was 24.7 per cent male, 60.4 per cent female, and 14.9 per cent lambs; the male to female ratio was therefore $40.9: 100$

Table 1. Population structure of 61 Gobi argali groups observed during ground surveys*

\begin{tabular}{|c|c|c|c|c|c|}
\hline & Male & Female & Lamb & Unknown & Total \\
\hline \multicolumn{6}{|l|}{ Omnogobi Aimag } \\
\hline Number (in 35 groups) & $38(24.7 \%)$ & $93(60.4 \%)$ & $23(14.9 \%)$ & 0 & 154 \\
\hline Mean & $1.1 \pm 0.3$ & $2.7 \pm 0.8$ & $0.7 \pm 0.2$ & - & $4.4 \pm 0.9$ \\
\hline \multicolumn{6}{|l|}{ Dornogobi Aimag } \\
\hline Number (in 26 groups) & $5(3.42 \%)$ & $67(45.9 \%)$ & $36(24.7 \%)$ & $38(26.0 \%)$ & 146 \\
\hline Mean & $0.2 \pm 0.1$ & $2.6 \pm 0.8$ & $1.4 \pm 0.5$ & $1.5 \pm 0.9$ & $5.6 \pm 1.3$ \\
\hline \multicolumn{6}{|l|}{ Overall } \\
\hline Number & $43(14.3 \%)$ & $160(53.3 \%)$ & $59(19.7 \%)$ & $38(12.7 \%)$ & 300 \\
\hline Mean & $0.7 \pm 0.2$ & $2.6 \pm 0.5$ & $1.0 \pm 0.2$ & $0.6 \pm 0.4$ & $4.9 \pm 0.8$ \\
\hline
\end{tabular}

* Means given are \pm standard errors. 
Figure 3. Mean ( $\pm \mathrm{SE}$ ) group sizes in which average members of each age-sex class found themselves (Jarman, 1982).

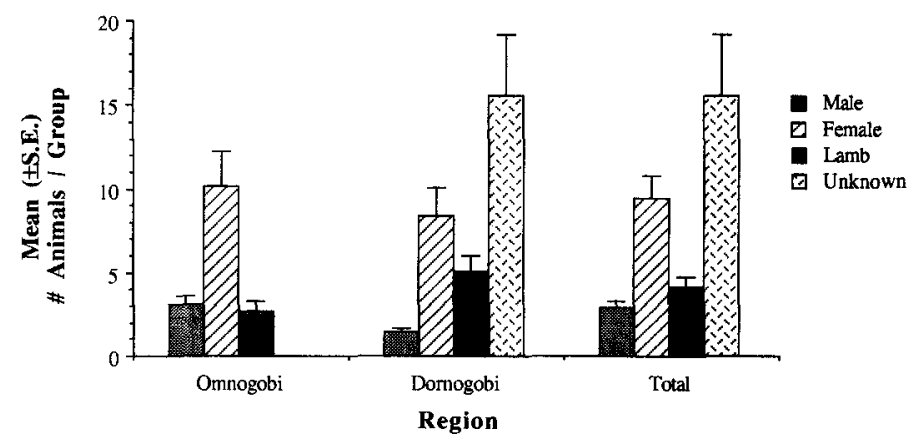

and the lamb to female ratio was $24.7: 100$. The average group size for 146 argali in 26 groups in Dornogobi aimag was $5.6 \pm 1.3 \mathrm{SE}$. The average group size of the two aimags was not significantly different $(t=-0.45$, d.f. $=25$, $P=0.66$ ). The Dornogobi argali population structure was 3.42 per cent male, 45.9 per cent female, 24.7 per cent lambs, and 26.0 per cent undetermined, giving male to female and lamb to female ratios of $7.5: 100$ and $53.7: 100$, respectively. There were significantly more males $(t=2.721$, d.f. $=25, P<0.05)$ in the argali groups of Omnogobi $(1.1 \pm 0.3 \mathrm{SE}$ males/group) than in Dornogobi $(0.2 \pm 0.1 \mathrm{SE}$ males/group). However, the population structure of argali groups in Omnogobi and Dornogobi did not differ significantly with respect to females $(t=0.48$, d.f. $=25, P=0.64)$ or lambs $(t=-1.03$, d.f. $=25, P=0.31$; Table 1$)$.

Measures of average group size are observer-centred and do not reflect the experiences of individual animals (Jarman, 1982). We therefore also calculated group size from the experience of individual animals following Jarman (1982; Figure 3). Overall, the average size of a group in which the average male finds itself is $2.9 \pm 0.4 \mathrm{SE}$, the average female is found in groups with a mean size of $9.5 \pm 1.4$

Table 2. Results of Gobi argali population and density estimation from aerial survey data using the DISTANCE program

\begin{tabular}{lccccc}
\hline Parameter & $\begin{array}{l}\text { Point } \\
\text { estimate }\end{array}$ & $\begin{array}{l}\text { Standard } \\
\text { error }\end{array}$ & $\begin{array}{l}\text { Per cent coef. } \\
\text { of variation }\end{array}$ & $\begin{array}{l}95 \% \\
\text { confidence interval }\end{array}$ \\
\hline & & & & & \\
$f(0)$ & 0.000973 & 0.0000829 & 8.52 & 0.000816 & 0.00116 \\
$P$ & 0.51 & 0.0438 & 8.52 & 0.43 & 0.61 \\
$E S W$ & 1030 & 87.60 & 8.52 & 862 & 1230 \\
$n / L$ & 0.00527 & 0.00108 & 20.41 & 0.00355 & 0.00783 \\
$D S$ & 0.00283 & 0.000627 & 22.12 & 0.00180 & 0.00446 \\
$E(S)$ & 6.58 & 1.24 & 18.78 & 4.48 & 9.68 \\
$D$ & 0.0187 & 0.00542 & 29.02 & 0.0105 & 0.03 .34 \\
$N$ & 3900 & 1130 & 29.02 & 2190 & 6960 \\
\hline
\end{tabular}

$f(0)$, value of the probability detection function at zero.

$P$, probability of observing an object in a defined area (in this case $2 \mathrm{~km}$ ).

$E S W$, effective strip width (actual strip width $/ P$ ).

$n / L$, number of groups sighted/line length in $\mathrm{km}$.

$D S$, estimated group density $/ \mathrm{sq} \mathrm{km}$.

$E(S)$, estimated expected value of group size.

$D$, estimated density of animals $/ \mathrm{sq} \mathrm{km}$.

$N$, population estimate. 
$\mathrm{SE}$, and the average lamb is one of $4.2 \pm 0.6 \mathrm{SE}$ animals in its group. Other than for unclassified individuals, group sizes from an individual animal's perspective were similar in Omnogobi and Dornogobi aimags.

In the aerial survey, we observed a total of 123 argali in 24 groups over $4552.5 \mathrm{~km}$ of transects covering 20.9 million ha. We were unable to determine sex or age class for most animals observed during the aerial survey and so excluded it from our analyses. Groups ranged in size from 1 to 19 animals (mean $5.1 \pm 1.2 \mathrm{SE}$ ). Average group sizes observed during ground and aerial surveys were not significantly different $(t=-0.73, \quad$ d.f. $=23, \quad P=0.47)$. Combining all group sightings from ground and aerial surveys, we observed a total of 423 argali in 85 groups for a mean group size of $5.0 \pm 0.6 \mathrm{SE}$ (range 1-29).

We analysed group size data from the Gobisteppe and semidesert areas separately. In the Gobi-steppe region of the aerial survey we observed a total of 21 argali in six groups ranging in size from 1 to 8 animals, with a mean group size of $3.5 \pm 1.0 \mathrm{SE}$. We observed 102 argali in 18 groups ranging in size from 1 to 19 animals, with a mean of $5.7 \pm 1.5 \mathrm{SE}$ in the semidesert region. The difference in argali group size in the Gobi-steppe and semi-desert regions was not significantly different $(t=$ 2.44 , d.f. $=5, P=0.06$ ).

Using the DISTANCE program we estimated the population of argali within the surveyed area to be $3900 \pm 1132$ SE (Table 2). The estimated density of argali was $0.0187 \pm 0.0054 \mathrm{SE}$ animals $/ \mathrm{sq} \mathrm{km}$ and estimated density of groups was $0.00283 \pm 0.00063 \mathrm{SE}$ groups $/ \mathrm{sq}$ $\mathrm{km}$ (Table 2). Although these densities are low, they include a large proportion of terrain, including nearly level steppe and semidesert areas, which do not contain argali habitat. Density estimates are therefore not comparable with results from studies which focused only on argali habitat. In addition, all analyses using the DISTANCE program should be considered rough estimates because we obtained a sample size of groups below the minimum of 40 recommended by designers of the programme (Burnham et al., 1980; White et al., 1989; Buckland et al., 1993).

\section{Discussion}

The ground survey found lamb to female ratios comparable to those reported from past studies (Table 3). Valdez and Frisina (1993) observed a total of 481 argali in southern and

Table 3. Comparison of Mongolian argali data collected in this study with previous studies

\begin{tabular}{|c|c|c|c|c|}
\hline \multirow[b]{2}{*}{ Study } & \multicolumn{2}{|l|}{ Ratios } & \multirow{2}{*}{$\begin{array}{l}\text { Mean group } \\
\text { size }( \pm \mathrm{SE})\end{array}$} & \multirow{2}{*}{$\begin{array}{l}\text { Dates } \\
\text { of survey }\end{array}$} \\
\hline & Lamb : F & $\mathrm{M}: \mathrm{F}$ & & \\
\hline \multicolumn{5}{|l|}{ This study } \\
\hline Aerial survey & - & - & $5.1 \pm 1.2$ & $10 / 94$ \\
\hline Overall ground surveys & $36.9: 100$ & $26.9: 100$ & $4.9 \pm 0.8$ & $8 / 94$ \\
\hline Omnogobi Aimag & $24.7: 100$ & $40.9: 100$ & $4.4 \pm 0.9$ & $8 / 94$ \\
\hline Dornogobi Aimag & $53.7: 100$ & $7.5: 100$ & $5.6 \pm 1.3$ & $8 / 94$ \\
\hline \multirow[t]{2}{*}{ Shanyavskii (1976) } & - & $92.5: 100$ & - & $9-10 / 74$ \\
\hline & - & $61.3: 100$ & - & $11 / 74 \& 6-11 / 75$ \\
\hline \multirow[t]{2}{*}{ Dzieciolowski et al. (1980) } & $16.0: 100$ & $84.7: 100$ & 39.2 & $2 / 79$ \\
\hline & $68.5: 100$ & $75.2: 100$ & 26.9 & $8 / 79$ \\
\hline Davaa et al. (1983) & $67.1: 100$ & $89.3: 100$ & - & $11 / 82$ \\
\hline Zhirnov and Ilyinsky (1986) & $59.9: 100$ & $76.9: 100$ & - & $1980-1982^{*} t$ \\
\hline Amgalanbaatar (1993b) & $48.1: 100$ & $52.6: 100$ & $12.1 \pm 2.4$ & $10-11 / 91 \& 9-11 / 92$ \\
\hline Valdez and Frisina (1993) & $75.0: 100$ & $129.8: 100$ & - & $9-10 / 93$ \\
\hline \multirow[t]{2}{*}{ Luschekina (1994) } & $16.0: 100$ & $81.3: 100$ & 8.7 & $1990^{*}$ \\
\hline & $11.0: 100$ & $73.0: 100$ & 5.8 & $8-9 / 93$ \\
\hline
\end{tabular}

* Months not specified. 
eastern Gobi (although the numbers they discuss do not match the number presented in their tables). They observed a ratio of lamb: female ratio of $75: 100$. Davaa et al. (1983) sighted 569 argali in the Gobi Altai region of Mongolia during the mid-1970s, noting a ratio of 67.1 lambs: 100 females. Zhirnov and Ilyinsky (1986) found a ratio of 59.9 lambs: 100 females in trans-Altai Mongolia. Luschekina (1994) surveyed argali in the Mongolian Altai Mountains and found ratios of 16 lambs: 100 females in 1990 and 11 lambs : 100 females in 1993. Amgalanbaatar (1993b) also studied argali in the Mongolian Altai, sighting 145 animals with a ratio of 48.1 lambs : 100 females. Dzieciolowski et al. (1980) surveyed a single reserve in the Mongolian Altai Mountains, observing ratios of 16 lambs : 100 females and 68.5 lambs: 100 females in the winter and summer, respectively.

Male to female ratios were more heavily skewed toward females in this study compared with other surveys (Table 3 ). Valdez and Frisina (1993) observed a ratio of 129.8 males : 100 females in 1993 in an overlapping region of the Gobi. Male to female ratios reported from the Gobi Altai vary from 92.5: 100 (Shanyavskii, 1976) to $89.3: 100$ (Davaa et al., 1983). In trans-Altai Mongolia, Zhirnov and Ilyinsky (1986) report a male to female ratio of $76.9: 100$. Finally, in the Mongolian Altai, other researchers found male to female ratios of 75.2-84.7:100 (Dzieciolowski et al., 1980), 81.3: 100 in 1990 (Luschekina, 1994), $73: 100$ in 1993 (Luschekina, 1994), $61.3: 100$ (Shanyavskii, 1976), and 52.6:100 (Amgalanbaatar, 1993b). The strong bias toward females in this study is not easily explained, but may have been partially a result of misclassification of young males as females. Alternatively, some male groups may have been missed or males may be more heavily hunted and poached.

Average group sizes found in this study (range $=3.5-5.7$ ) were smaller than group sizes reported for Mongolian Altai argali (Table 3). Luschekina (1994) reported average group sizes of 8.7 argali/group in 1990 and 5.8 argali/group in 1993 in the Mongolian Altai. Amgalanbaatar (1993b) sighted 12 groups with 145 animals in the Mongolian Altai.
Average group size from his study was $12.1 \pm$ 2.4 SE (range 2-32), and although his sample size was small, group size was significantly greater $(t=4.61$, d.f. $=11, P<0.01)$ than group sizes observed in this study $(4.9 \pm 0.6 \mathrm{SE})$. Dzieciolowskiw et al. (1980) observed even larger groups of argali in the Altai, averaging 26.9-39.2 animals/group. The smaller group sizes found in this study probably reflect the harsher environmental conditions of the Gobi compared with the Altai Mountains.

The density of argali estimated from the aerial survey $(0.019 \pm 0.005 \mathrm{SE}$ argali $/ \mathrm{sq} \mathrm{km})$ was low, especially when compared with density estimates reported elsewhere for argali; however, the aerial survey covered a substantial amount of unsuitable habitat, which we were unable to eliminate from our analyses. Other reported densities for argali in the Gobi Altai (the closest region for which estimates are reported) are 0.06/sq km (Berdar, 1975, in Luschekina, 1994), 0.13/sq km (Sukhbat, 1975), and $0.9-1.5 / \mathrm{sq} \mathrm{km} \mathrm{(Sukhbat} \mathrm{and}$ Gruzdev, 1986), and 0.3-2.1 animals/sq km (Valdez and Frisina, 1993). Densities of argali in other parts of Mongolia range from 0.02 to $2.30 / \mathrm{sq} \mathrm{km}$ in the Mongolian Altai region (Sukhbat, 1975; Mallon, 1985b; Sukhbat and Gruzdev, 1986; Fish and Wildlife Research Institute, 1992a, 1993a,b; Amgalanbaatar, 1993a,b; Amgalanbaatar et al., 1993; Luschekina, 1994), $0.002-0.06 / \mathrm{sq} \mathrm{km}$ in the trans-Altai (Zhirnov and Ilyinsky, 1986; Sukhbat and Gruzdev, 1986), 0.11-0.33/sq $\mathrm{km}$ in Khovsgol Aimag (Sukhbat and Gruzdev, 1986; Fish and Wildlife Research Institute, 1992b; Amgalanbaatar, 1993) and $0.33 / \mathrm{sq} \mathrm{km}$ in Khentie Aimag (Amgalanbaatar, 1993). For comparison, Fox et al. (1991) reported densities of $0.2-0.4 / \mathrm{sq} \mathrm{km}$ for a heavily hunted Tibetan argali (O. a. hodgsoni) population in Ladakh, India.

Our population estimate of $3900 \pm 1132$ SE represents only a portion of the Gobi argali population. Several researchers calculated simple population estimates based on numbers of animals per area sampled multiplied by all potential argali habitat. Sukhbat (1975) estimated a population size of 3870 argali in the Gobi Altai and Berdar (1975, in 
Luschekina, 1994) estimated that 5000 argali inhabited the region. Valdez and Frisina (1993) provided population estimates for smaller areas within a region overlapping this study site, including $1534 \pm 307$ animals in Ikh Nartiin, $242 \pm 18$ animals in Modon Usnii, 92 \pm 18 animals in Shar Harhaan, and $461 \pm 92$ animals in Hutag (no indication of what the ranges surrounding each estimate is provided).

Population estimates for the whole of Mongolia vary considerably, with some researchers expressing concern for the status of the species and others suggesting that the argali is relatively widespread and not threatened (see review in Luschekina, 1994). The Institute of General Experimental Biology of the Mongolian Academy of Sciences surveyed argali sporadically from 1960 to 1980 and estimated the total population in Mongolia to be c. 50,000 animals (Amgalanbaatar, 1993a). The Mongolian Hunter's Association estimated that 40,000 argali inhabited Mongolia in 1970 (Amgalanbaatar, 1993a.). These estimates are in contrast to Shanyavskii (1976), who estimated the population of Mongolian argali to be 10,000-12,000 animals. Similarly, Gruzdev and Sukhbat (1982) estimated 12,000 argali in Mongolia. However, just a few years later these same authors estimated argali numbers at between 18,000 and 20,000 individuals (Grudev et al., 1985). Finally, Luschekina (1994: 26) suggested that 'no more than 20,000' argali exist in Mongolia. More systematic, rigorous and comprehensive surveys for argali are clearly required for more accurate estimates of numbers and distribution. This requires surveying, and subsequently managing, argali by region. Preferably distinct populations should be determined and managed as such, but at a minimum the taxonomic status of argali subspecies in Mongolia should be resolved and the species managed at that level.

More active argali conservation and management should be pursued. Perhaps the greatest challenges to argali conservation are poaching and competition with domestic livestock. Several authors have identified poaching as a major cause of argali mortality, even within protected areas (Zhirnov and Ilyinsky, 1986; Shagdarsuren et al., 1987; Luschekina, 1994; Mallon et al., 1997). Similarly, overgrazing and displacement by livestock has substantially reduced and degraded argali habitat (Gruzdev and Sukhbat, 1982; Zhirnov and Ilyinsky, 1986; Shagdarsuren et al., 1987; Amgalanbaatar and McCarthy, 1993; Luschekina, 1994; Mallon et al., 1997). Alternatively, Mongolia has expanded its protected-area system greatly since 1991 and argali currently inhabit or recently inhabited 16 protected areas in Mongolia, namely Khokh Serkhiin, Eej Uul, Ikh Gobi, Gurvan Saikhan Uul, Khasagt Khairkhan, Khovsgol Nuur, Otgontenger Uul, Uvs Nuur (Ministry for Nature and the Environment, 1996), and the newly (summer 1996) established Alag Khairkhan Uul, Burkhan Buudai Uul, Ergeliin Zoo Niit, Suikhent Niit, Ikh Nart, Zagiin Usni, Altai Tavan Bogd and Khungai Nuruu protected areas. However, both poaching and overgrazing are prevalent throughout most of these protected areas (Mallon et al., 1997). More active management is necessary, including active antipoaching activities and, to the extent feasible, gradual movement of people and livestock out of protected areas. Sport hunting should be permitted only if argali populations are more carefully managed and deemed capable of sustaining such harvests. At least a substantial portion of money generated from sports hunting should be directed toward management of argali and their habitat. Funds should go to increasing ranger staff, equipment and training, and to more rigorous and regular argali surveys and research (see also Mallon et al., 1997). Without more active conservation management measures, Mongolia risks further declines in argali numbers and distribution, including the imminent loss of several populations.

\section{Acknowledgments}

We would like to thank all of the individuals who took part in both surveys. Special thanks go to L. Amgalan, O. Batbold, Z. Batjargal, U. Buyandelger, J. Griffin, M. Johnstad, and G. Schaller. A. Laurie, D. Mallon and D. Shackleton provided helpful comments on earlier drafts of the manuscript. Funding 
was provided by the Society for the Conservation of the Mongolian Gazelle, Brandenburg Ministry for Nature and the Environment, the Mongolian Ministry for Nature and the Environment, the Mongolian Hunting Association, the Mongolian Forestry and Hunting Institute, Wildlife Conservation International, WWF-Germany, and the United Nations Development Programme/ Global Environment Facility, and Mongolian Ministry for Nature and the Environment's Mongolian Biodiversity Project.

\section{References}

Amgalanbaatar, S. 1993a (In press). Argali population inventory and conservation measures in selected areas of Mongolia. Research Papers Forest and Hunting Institute. (In Mongolian.)

Amgalanbaatar, S. 1993b. Population and Ecological Status of Argali in Some Locations of the Western Altai Mountains. Unpublished report. Forestry and Hunting Institute, Ulaanbaatar, Mongolia. 5 pp. (In Mongolian).

Amgalanbaatar, S., Battulga, B. and Tsogtsaikhan, P. 1993. The numbers, distribution and ecological status of mountain ungulates in Uvs Aimag. In Proceedings from a Conference on the Status of Nature and Biological Resources in Western Mongolia and Adjacent Areas, 13-17 April 1993, Hovd Pedagogical University, (ed. Kh. Terbish), pp. 53-54. Orchlon Co., Ulaanbaatar, Mongolia. (In Mongolian.)

Amgalanbaatar, S. and McCarthy, T. 1993. Hovd/Khokh Serhiim Reserve Trip Report. Unpublished report. Mongolia Biodiversity Project, Ulaanbaatar, Mongolia.

Berdar, B. 1975. Wild range game counts in Mongolia. Nimr-d, 10, 4-6. (In Hungarian.)

Buckland, S.T., Anderson, D.R., Burnham, K.P. and Laake, J.L. 1993. Distance Sampling: Estimating Abundance of Biological Populations. Chapman \& Hall, London.

Burnham, K.P., Anderson, D.R. and Laake, J.L. 1980. Estimation of density from line transect sampling of biological populations. Wildlife Monographs, 72, 1-202.

Burnham, K.P., Anderson, D.R. and Laake, J.L. 1985. Efficiency and bias in strip and line transect sampling. Journal of Wildlife Management, 49, 1012-1018.

Davaa, N., Sukhbat, Kh. and Stubbe, M. 1983. Contribution to the understanding of ecology and morphology of Ovis ammon L., 1758 in the MPR. Erforschung Biologischer Ressourcen der Mongolischen Volksrepublik, 3, 61-65. (In German.)

Dzieciolowski, R., Krupka, J., Bajandelger, and Dziedzic, R. 1980. Argali and Siberian ibex popu- lations in the Kuhusyrh Reserve in Mongolian Altai. Acta Theriologica, 25, 213-219.

Dulamtseren, S. 1970. Guidebook to the Mammals of the Mongolian People's Republic. Mongolian State Publishing House, Ulaanbaatar, Mongolia. (In Mongolian.)

Forestry and Wildlife Research Institute. 1992a. The Status of Game Species and their Habitats in BayanOlgii Aimag, with Recommendations for Use and Protection. Forestry and Wildlife Research Institute, Ministry for Nature and the Environment, Ulaanbaatar, Mongolia. (In Mongolian.)

Forestry and Wildlife Research Institute. 1992b. The Status of Game Species and their Habitats in Khovsgol Aimag, with Recommendations for Use and Protection. Forestry and Wildlife Research Institute, Ministry for Nature and the Environment, Ulaanbaatar, Mongolia. (In Mongolian.)

Forestry and Wildlife Research Institute. 1993a. The Status of Game Species and their Habitats in GobiAltai Aimag, with Recommendations for Use and Protection. Forestry and Wildlife Research Institute, Ministry for Nature and the Environment, Ulaanbaatar, Mongolia. (In Mongolian.)

Forestry and Wildlife Research Institute. 1993b. The Status of Game Species and their Habitats in Khovd Aimag, with Recommendations for Use and Protection. Forestry and Wildlife Research Institute, Ministry for Nature and the Environment, Ulaanbaatar, Mongolia. (In Mongolian.)

Fox, J.L., Nurbu, C. and Chundawat, R.S. 1991. The mountain ungulates of Ladakh, India. Biological Conservation, 58, 167-190.

Geist, V. 1991. On taxonomy of giant sheep (Ovis ammon Linneaus, 1766). Canadian Journal of Zoology, 69, 706-723.

Gruzdev, V. and Sukhbat, Kh. 1982. Mountain ungulates of Mongolia. Hunting and Hunting Farms, 9, 41-43. (In Russian.)

Gruzdev, V., Sukhbat, Kh. and Ierengochoo, Kh. 1985. Species composition and the distribution of game animals in the Cis-Khovsgol region. In Natural Conditions of the Cis-Khovsgol Region. Irkutsk, Russia. (In Russian.)

IUCN. 1996. 1996 IUCN Red List of Threatened Animals. IUCN, Gland, Switzerland.

Jarman, P. 1982. Prospects for interspecific comparison in sociobiology. In Current Problems in Sociobiology (ed. King's College Sociobiology Group), pp. 323-342. Cambridge University Press, London.

Laake, J.L., Buckland, S.T., Anderson, D.R. and Burnham, K.P. 1993. Distance User's Guide V2.0. 
Colorado Cooperative Fish and Wildlife Research Unit, Colorado State University, Fort Collins, Colorado, USA.

Luschekina, A. 1994. The Status of Argali in Kirgizstan, Tadjikistan and Mongolia. Unpublished report. Office of Scientific Authority, US Fish \& Wildlife Service, Arlington, Virginia, USA.

Mallon, D.P. 1985a. The mammals of the Mongolian People's Republic. Mammal Review, 15, 71-102.

Mallon, D.P. 1985b. Wild sheep in Mongolia. In Wild Sheep: Distribution, Abundance, Management and Conservation of the Sheep of the World and Closely Related Mountain Ungulates (ed. M. Hoefs), pp. 179-187. Northern Wild Sheep and Goat Council, Whitehorse, Yukon, Canada.

Mallon, D. P., Bold, A., Dulamtseren, S., Reading, R. P. and Amgalanbaatar, S. 1997. Mongolia. In Wild Sheep and Goats and their Relatives: Status Survey and Action Plan for Caprinae (ed. D. Shackleton and the IUCN/SSC Caprinae Specialist Group), pp. 193-201. IUCN, Gland, Switzerland.

Ministry for Nature and the Environment. 1996. Biodiversity Conservation Action Plan for Mongolia. Ministry for Nature and the Environment, Ulaanbaatar, Mongolia.

Nowak, R. 1993. Court upholds controls on imports of argali trophies. Endangered Species Technical Bulletin, 18 (4), 11-12.

Schaller, G. B. 1994. A Preliminary Resource Survey of the Eastern Gobi, August 1994. Unpublished report. Mongolia Biodiversity Project, Ulaanbaatar, Mongolia.

Shagdarsuren, O., Jigj, S., Tsendjav, D., Dulamtseren, S., Bold, A., Monkbayar, Kh., Dulmaa, A., Erdenjav, G., Ulziihutag, Kh., Ligaa, U. and Sanchir, C. 1987. Red Book of the Mongolian People's Republic. Mongolian State Publishing House, Ulaanbaatar, Mongolia. (In Mongolian.)

Shanyavskii, A. 1976. Development of Forestry and Hunting Farms. Unpublished report. Mongolian Ministry of Forestry, Ulaanbaatar, Mongolia. (In Russian.)

Sukhbat, Kh. 1975. Census of mountain ungulates in the Mongolian and Gobi Altai. In Problems of Game Management and Nature Conservation, pp. 165-167. Irkutsk Agriculture Institute, Irkutsk, Russia. (In Russian.)

Sukhbat, Kh. 1978. Distribution of Mongolian argali. Research of the Mongolian Academy of Science's Institute of General and Experimental Biology, 13, 81-86. (In Mongolian.)
Sukhbat, Kh. and Gruzdev, V.B. 1986. The mountain sheep argali in the Mongolian People's Republic. In Natural Conditions and Biological Resources of the Mongolian People's Republic, p. 195. Moscow. (In Russian.)

Tsalkin, V.I. 1951. Wild Mountain Sheep of Europe and Asia. Moscow Association for Nature Research, Moscow. (In Russian.)

Tsegmid, Sh. and Vorobev, V.V. (eds). 1990. Mongolian People's Republic Land Atlas. USSR Department of Geodesy and Cartography, and Mongolian Department of Geodesy and Cartography, Moscow. (In Mongolian with some English.)

Valdez, R. and Frisina, M. 1993. Wild Sheep Surveys in Eastern and Central Gobi Desert and Altai Mountains, Mongolia. Unpublished report. Mongolia Biodiversity Project, Ulaanbaatar, Mongolia.

White, G.C., Bartman, R.M., Carpenter, L.H. and Garrott, R.A. 1989. Evaluation of aerial line transects for estimating mule deer densities. Journal of Wildlife Management, 53, 625-635.

Wingard, J.R. 1996. Report on Mongolian Environmental Laws. Mongolia Biodiversity Project, Ministry for Nature and the Environment, Ulaanbaatar, Mongolia.

Zhirnov, L.V. and Ilyinsky, V.O. 1986. The Great Gobi Reserve - a Refuge for Rare Animals of the Central Asian Deserts. USSR/UNEP Project, Programme for Publication and Informational Support, Centre for International Projects, GKNT, Moscow.

Richard P. Reading, Denver Zoological Foundation \& Northern Rockies Conservation Cooperative, 2300 Steele St, City Park, Denver CO 80205, USA.

Sukhiin Amgalanbaatar, Mongolia Biodiversity Project \& Forestry and Hunting Institute, Ministry for Nature and the Environment, Khudaldaany gudamj-5, Ulaanbaatar 11, Mongolia.

Henry Mix, Nature Conservation International, Reinhardstrasse 10, D-10117 Berlin, Germany.

Badamjaviin Lhagvasuren, Institute of General and Experimental Biology, Mongolia Academy of Science and Society for the Conservation of Mongolian Gazelle, Ulaanbaatar 51, Mongolia. 